\title{
DETERMINATION OF SURFACTANTS IN ENVIRONMENTAL SAMPLES. PART III. NON-IONIC COMPOUNDS ${ }^{4}$
}

\author{
OZNACZANIE POZIOMÓW ZAWARTOŚCI SURFAKTANTÓW \\ W PRÓBKACH ŚRODOWISKOWYCH. CZĘŚĆ III. NIEJONOWE ZWIĄZKI
}

\begin{abstract}
Non-ionic surface active agents are a diverse group of chemicals which have an uncharged polar head and a non-polar tail. They have different properties due to amphiphilic structure of their molecules. Commercial available non-ionic surfactants consist of the broadest spectrum of compounds in comparison with other types of such agents. Typically, non-ionic compounds found applications in households and industry during formulation of cleaning products, cosmetics, paints, preservative coatings, resins, textiles, pulp and paper, petroleum products or pesticides. Their are one of the most common use class of surfactants which can be potential pollution sources of the different compartment of environment (because of they widely application or discharging treated wastewaters to surface water and sludge in agricultural). It is important to investigate the behavior, environmental fate of non-ionic surfactants and their impact on living organisms (they are toxic and/or can disrupt endocrine functions). To solve such problems should be applied appropriated analytical tools. Sample preparation step is one of the most critical part of analytical procedures in determination of different compounds in environmental matrices. Traditional extraction techniques (LLE - for liquid samples; SLE - for solid samples) are time and solvent-consuming. Developments in this field result in improving isolation efficiency and decreasing solvent consumption (eg SPE and SPME - liquid samples or PLE, SFE and MAE - solid samples). At final determination step can be applied spectrophotometric technique, potentiometric titrametration or tensammetry (determination total concentration of non-ionic surfactants) or chromatographic techniques coupled with appropriated detection techniques (individual analytes). The literature data concerning the concentrations of non-ionic surfactants in the different compartments of the environment can give general view that various ecosystems are polluted by those compounds.
\end{abstract}

Keywords: non-ionic surfactants, isolation and/or enrichment, final determination, environmental samples

\section{Introduction}

Non-ionic surfactants are a diverse group of chemicals that are designed to have various types of properties. They consist of an uncharged polar head (polyether or

\footnotetext{
${ }^{1}$ Gdańsk University of Technology, ul. G. Narutowicza 11/12, 80-233 Gdańsk, Poland, phone +48 583472110 , fax +48583472694, email: chemanal@pg.gda.pl

${ }^{2}$ Faculty of Earth Sciences, University of Silesia, ul. Będzińska 60, Sosnowiec 41-200, Poland

${ }^{3}$ Department of Forest Ecology, Forest Research Institute, Sękocin Stary, ul. Braci Leśnej 3, 05-090 Raszyn, Poland

* Corresponding author: zanpolko@pg.gda.pl

${ }^{4}$ Part I: ECE S 2013;20(1):69-77, Part II: ECE S 2013;20(2):331-342
} 
polyhydroxyl units), which is well soluble in water, and a non-polar tail (hydrocarbon), which is not or not easily dissolved in aqueous solution [1]. Typically, in the polar chain number of ethoxylates units (EO) is five to ten (except dispersant molecules - they have longer chains). The most commonly used materials for production of non-ionic surfactants are: fatty alcohols, fatty acids, fatty amines, alkylphenoles and esters. The examples of compounds from group of non-ionic surfactants are given in Figure 1.

Commercial available non-ionic surfactants consist of the broadest spectrum of compounds in comparison with other types of surface active agents. For example, fatty acid ethoxylates are complex mixtures of high amount of polyethylene glycol and fatty alcohol ethoxylates as by-products. They may be applied during formulation of liquid and powder detergents in household and industry areas of human activity. Compounds from the group of polyhydroxy (polyol)-based (eg sucrose esters, sorbitan esters, alkyl glucosides, polyglycerol esters) have complicated molecule structure. Some of them can be applied during composition of food or drugs (sorbitan ester surfactants) or as antifoaming agents (acetylenic glycols) [2, 3].

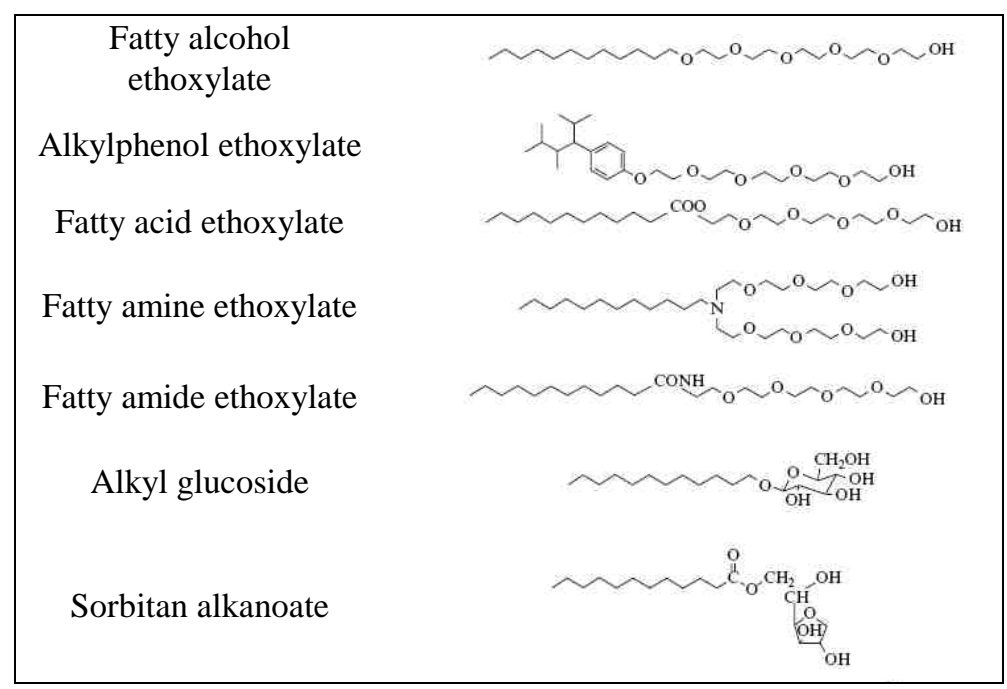

Fig. 1. The examples of compounds from group of non-ionic surfactants

Non-ionic surface active agents found applications as household and industrial detergents, emulsifiers, wetting and dispersing agents. Non-ionic compounds can be used in formulation of cleaning products, cosmetics, paints, preservative coatings, resins, textiles, pulp and paper, petroleum products or pesticides [4-6].

To the group of alkylphenol ethoxylates (APEO), which are widely applied in different areas, are bellow compounds like nonylphenol (NPEO) and octylphenol ethoxylates (OPEO). Those compounds undergo a quick degradation in wastewater treatment plants (WWTP) into short-chain alkylphenol ethoxylates (alkylphenols (AP) - octylphenol (OP) and nonylphenol (NP)) and carboxylated derivatives (eg alkylphenoxyethoxy carboxylates (APEC)). Non-ionic compounds presents bioaccumulation in aquatic organism and chronic toxicity to them (Table 1). Moreover, it should be noticed that products of APEO 
metabolism are toxic due to their estrogenic properties and they can influent on biota after exposure to WWTP effluents as endocrine disrupting chemicals [7].

Non-ionic surfactant are one of the most common use compounds which can be potential emit to the different compartment of environment during their application or through treated wastewaters and sludge. It becomes more and more important to investigate the environmental fate of surfactants. Such research requires development of appropriated analytical tools in order to obtain information about surfactant and their sometimes more toxic recalcitrant metabolites [8].

The toxicity of several compounds from the group of non-ionic surfactants

Table 1

\begin{tabular}{|c|c|c|c|c|}
\hline Analyte & Test organism & $\begin{array}{c}\text { Toxicity } \\
\text { parameter }\end{array}$ & $\begin{array}{c}\text { Concentration } \\
{[\mathrm{mg} / \mathrm{L}]}\end{array}$ & $\begin{array}{l}\text { Litera- } \\
\text { ture }\end{array}$ \\
\hline NP & Daphnia magna & \multirow{3}{*}{$\mathrm{LC}_{50}(48 \mathrm{~h})^{2)}$} & 0.19 & \multirow{2}{*}{ [9] } \\
\hline \multirow{2}{*}{ NPEO } & Daphnia magna & & 14 & \\
\hline & Mysidopsis bahia & & $1.2-1.9$ & [10] \\
\hline \multirow{5}{*}{$\mathrm{AE}^{1)}$} & $\begin{array}{c}\text { Raphidocelis } \\
\text { subcapitata }\end{array}$ & $\mathrm{IC}_{50}(72 \mathrm{~h})^{3)}$ & 6.9 & \multirow{3}{*}{ [11] } \\
\hline & Physella acuta & \multirow{2}{*}{$\mathrm{LC}_{50}(24 \mathrm{~h})^{2)}$} & $4.0-7.4$ & \\
\hline & Artemia salina & & $0.58-0.67$ & \\
\hline & Carassius auratus & \multirow{2}{*}{$\mathrm{EC}_{50}(48 \mathrm{~h})^{4)}$} & 29 & \multirow{2}{*}{ [12] } \\
\hline & Salmo gairdneri & & 22 & \\
\hline
\end{tabular}

1) $\mathrm{AE}$ - alcohol ethoxylate

${ }^{2)} \mathrm{LC}_{50}$ - lethal dose - concentration of substance, which kills $50 \%$ of the population after 24,48 or 72 hours

${ }^{3)} \mathrm{IC}_{50}$ - inhibitory concentration - causes weakness in a specific process of $50 \%$ of its maximum value after 24 , 48 or 72 hours

${ }^{4)} \mathrm{EC}_{50}$ - effective concentration - concentration of substance that causes specific biological effect of $50 \%$ of its maximum value after 24,48 or 72 hours

\section{Sample preparation step}

\section{Liquid samples}

The liquid-liquid extraction (LLE) is widely used at sample preparation step during the determination of concentration of ionic and non-ionic surface active agents. In this technique, separation process is based on distribution of analytes between two immiscible liquid phases - aqueous samples and organic solvents. Due to this conception appropriate organic solvent (dichloromethane (DCM), ethyl acetate (EA)) is added to sample to isolation non-ionic surfactants $[13,14]$. To overcome problem with the formation of emulsion during the phase separation are applied specific ion-pair reagent (modified Dragendorff reagent - anionic complex species of bismuth(III) and iodides - for non-ionic $[13,15])$. This procedure leads to formation of hydrophobic ion-pairs and analytes can be separated from aqueous samples with organic phase. The liquid-liquid extraction offers simple isolation of analytes from matrices without use of sophisticated equipment. But on the other hand, it is time- and solvent- consuming process with use of toxic agents.

Nowadays, the LLE is replacing by solid phase extraction at sample preparation step of liquid samples. The SPE technique is often applied for chemical isolation of analytes from complex matrices and purification of received extracts. In comparison to LLE technique, the solid phase extraction allows for reduction of analytes isolation time and consumption of 
solvents [16]. Moreover, the sample preparation step can be automated with use of SPE [17]. Several types of sorbents (graphitized black carbon, octadecylsilica or polymeric) were employed for the extraction of non-ionic compounds from environmental samples. Graphitized carbon black, non-porous sorbent, is used in solid phase extraction of compounds from the group of alkylphenol ethoxylates. In this case, the isolation of analytes is slower (due to high resistance to the water flow) than with polymeric or C18 sorbent and interferences are co-extracted (non-selective sorbent) [7]. The octadecylsilica sorbents allow for achieve high recoveries for different alkylphenol ethoxylates oligomers and low for nonylphenols and octylephenols [18, 19]. The use of GCB or $\mathrm{C}_{18}$ sorbents give possibility to isolation of anionic (LAS, SPC, AES) and non-ionic (APEO, APEC, NP) surface active compounds in single extraction [20-22].The highly cross-linked PSDB (polymeric sorbent) was used for simultaneous isolation of APs, short-chain $\mathrm{AP}_{1-5}$ EOs [23] and long-chain $\mathrm{AP}_{6-16} \mathrm{EOs}$ (low recoveries for long-chain compounds) [7]. The comparison of octadecylsilica and polymeric sorbents applied for isolation of non-ionic SAA from liquid samples provide to conclusions that both sorbents have obtained similar recoveries of analytes, but polymeric sorbent allows for faster extraction of larger sample volumes [7, 23]. Other hydrophilic polymeric sorbents (hydrophilic macroporous poly(N-vinylpyrrolidone-divinylbenzene) copolymer) were studied for simultaneous isolation of alkylphenols, short chain alkylphenol ethoxylates $\left(\mathrm{AP}_{1-2} \mathrm{EO}\right)$ and their more polar metabolites. During experiments were reported high recoveries for metabolites of APEO compounds $\left(\mathrm{NP}_{1} \mathrm{EC}-110 \%\right.$; $\left.\mathrm{OP}_{1} \mathrm{EC}-99 \%\right)$. Lower recoveries were achieved for OP and $\mathrm{OP}_{1-2} \mathrm{EO}(\sim 80 \%)$ and the lowest for NP and NPEO $(<70 \%)$ [24]. This type of extraction sorbent was also employed to extraction of alkylphenols, alkylphenol ethoxylates with more than 5 units of EO groups and their acidic metabolites (APEC) from WWTP effluent and surface waters and it gives higher recoveries than previously described polymeric sorbents [25]. The higher recoveries of wide range of non-ionic analytes can be achieved with use of sequential solid phase extraction (SSPE). In this procedures cartridges with different sorption material are coupled in series (eg $\mathrm{C}_{18}$ with ionic strong anion- and cation-exchange) and solvent used at elution step (selective desorption) [26-28].

Due to requirements of green analytical chemistry there is emphasis on developing and application sample preparation techniques which are environmentally friendly [29]. To isolation of non-ionic analytes from aqueous environmental samples were used following techniques:

- $\quad$ dispersive liquid-liquid microextraction (DLLME) [30, 31];

- $\quad$ hollow-fiber liquid phase microextraction (HF-LPME) [32];

- $\quad$ solid-phase microextraction (SPME) [19, 33-37].

In recent years, a novel analytical technique dispersive liquid-liquid microextraction (DLLME) was employed to isolation of non-ionic surfactants from liquid samples. In DLLME technique, analytes (OP, NP, $\left.\mathrm{AP}_{1-2} \mathrm{EO}\right)$ were extracted from aqueous sample by their migration to appropriate extracting solvent characterized by low soluble in water (eg trichloroethylene, chloroform). To samples is added also second dispersing solvent which is soluble in water (eg acetone, methanol). The cloudy solution was separated by centrifugation and subjected to chromatographic system [30, 31].

The hollow-fiber membrane-assisted liquid-phase microextraction also was applied to isolation of non-ionic compounds (nonylphenols, octylphenols) from environmental samples. This extraction technique is based on the dissolved analytes into a micrometer 
liquid membrane of 1-octanol, which is held by a porous polypropylene hollow fiber. This HF-LPME technique gives solution of main difficulties occurred during application of DLLME (automation of sample preparation step, vulnerability of solvent drop to physic forces) [32].

Two other environmental friendly techniques were employed for isolation of non-ionic analytes: solid-phases microextraction and stir bar sorptive extraction. The SPME technique gives possibility to eliminate toxic solvents from sample preparation step because analytes are directly adsorbed on the fiber surface from aqueous solutions. After isolation the SPME device is transfer to injection port of chromatographic systems and analytes are desorbed into stream of mobile phase [33]. Several coated fibers were employed for the isolation of analytes: Carbowax/template resin (CWAX-TR), Carbowax-divinylbenzene (CWAXDVB), polydimethylsiloxane-template resin (PDMS-TR), polydimethylsiloxanedivinylbenzene (PDMS-DVB), polyacrylate (PA) [33, 34]. Before analysis of solvent extracts with gas chromatography non-ionic with higher molecular weight should be derivatized with specific agents (trimethylchlorosilane with BSTFA [33], N-tert-butyldimethylsilyl- $N$-methyltrifluoroacetamid (MTBSTFA) [35] or with $1 \%$ tert-butyldimethylchlorosilane (TBDMCS) [34]). This technique was used to isolation analytes from the group of APEO from sewage sludge samples [33], short-chain nonylphenols from river water [36], alkylphenols (4-tert-octylphenol, nonylphenol isomers, 4-nonylphenol) from tap and lake water [34], from wastewater [37] and coastal water samples [35].

\section{Solid samples}

The Soxhlet extraction technique was several times applied to isolation of non-ionic surfactants (short-chain nonylophenols, long-chain alkylphenol ethoxylate, nonylphenols, octylphenols) from solid samples. It is simple extraction technique and does not require expensive equipment. However, there is a need of use very large volume of solvents (mainly $50-300 \mathrm{~cm}^{3}$ of methanol, dihloromethane) and isolation time of analytes is very long (up to 48 hours) [38-40].

Recently, other isolation techniques were applied at sample preparation step, in which different parameters improve the solubility of solid samples (high temperature and pressure, application of ultrasounds or microwaves).

Ultrasounds-assisted extraction (UAE) is an alternative technique to the traditional extraction systems. It gives possibility to faster isolation of analytes than in Soxhlet apparatus and to reduce large volumes of toxic organic solvents $\left(30-60 \mathrm{~cm}^{3}\right.$ of mixtures of acetone, hexane, and dichloromethane) [38].

The accelerated solvent extraction (ASE) is the main extraction technique used for extraction of non-ionic compounds from solid matrices. The ASE offers such advantages as faster sample preparation, reduction of solvent consumption $\left(15-30 \mathrm{~cm}^{3}\right.$ of acetonitrile, water, methanol, acetone, dichloromethane or their mixtures) and possibility of automation isolation stage. The ASE technique allows for efficient extraction of a wide range of alkylphenols and alkylphenol ethoxylate oligomers even in complex matrices like sludge [7, 41], soil [41, 42] and bottom sediment [43].

The microwave-assisted extraction (MAE) has become a technique which is used to isolation of non-ionic surfactants (NP, OP, NPEO) from environmental particulate samples such as sediments. The MAE technique has such improvement as small volume of solvent (mainly $\mathrm{MeOH}, \mathrm{DCM} / \mathrm{MeOH}$ ) and amount of samples, short time of extraction and 
simultaneously preparation many samples. The high initial cost of MAE apparatus is pay-back due to solvent amount saving and short time of isolation analytes [44-46].

Only several times the supercritical fluid extraction (SFE) was used to isolation compounds from groups of non-ionic surface active agent (NPEO and their metabolites, OP, $\mathrm{NP})$ in solid matrices [39]. In mentioned technique the extractants $\left(\mathrm{CO}_{2}\right.$ or water) are non-toxic, cheap, has ability to dissolve different types of organic compounds and they could be easily remove from samples. The modification of extracting medium with low molecular weight polar compounds (eg $\mathrm{MeOH}, \mathrm{EtOH}$, water) resolves problems with low recoveries during isolation of long-chain APEOs [47-50].

\section{Final determination step}

The determination of total concentration of surfactants or their individual levels requires the use of appropriated analytical techniques during analysis of solvent extracts.

In first analytical issue can be solved by spectrophotometry [51], potentiometric titrametration (PT) [52, 53] and tensammetry [54, 55].

Titrimetric technique can be used only to determine higher concentrations of non-ionic compounds and interfering substances can influent on final results. The PT technique was used to analysis levels of total concentration of non-ionic surface active agents in wastewater and sea water samples [52, 53].

Tensammetric technique allows for the determination of total concentration of non-ionic SAA and results are similar to those with use of formation of complex of the BiAS or CTAS with analytes and spectrophotometry. Tensammetry belongs to the group of voltammetric techniques, where used changes of double layer capacity are and it allows for the determination of non-ionic compounds. More specific procedure includes application of the BiAS separation scheme with the tensammetric measurement. This technique was applied for analysis of river water samples [54, 55].

Spectrophotometric technique is universal for final determination of total concentration of different types of surfactants. This technique is based on the reaction of the polyoxyethylene chain with metal cations, next the ion-pairs are extracted into organic solvents and the absorbance of organic layer is measuring. But it should be noticed that with non-ionic analytes are co-existed cationic and anionic compounds cause errors during final analysis [51]. Procedures involve use of this technique are not environmental friendly and they should be replaced by other one.

To receive information about environmental fate of non-ionic surfactants it is necessary to develop and applied different analytical techniques for the determination of these substances in different matrices at trace levels. The gas chromatography (GC) coupled to mass spectrometry (GC-MS) is powerful tool for separation, qualitative and quantity analysis of different types organic compounds, however, it is limited by their volatility (only to NP, OP, and $\mathrm{AP}_{1-3} \mathrm{EO}$ ). The determination of concentration of long-chain APEO compounds requires the use of derivatization step in the analytical procedures. Also flame ionization detection (FID) coupled with GC system can be applied for determination of levels of individual non-ionic compounds [16, 33-36].

The liquid chromatography (LC) is the most powerful and universal analytical technique for analysis of solvent extracts. Chromatographic separation of compounds from the group of APEOs and their metabolites in a single analysis presents several difficulties 
(complexities of commercially-available technical products, broad range of polarities that APEOs - more lipophilic APs and more hydrophilic long-chain oligomers) [16]. The LC technique is suitable to determination of low-volatility compounds with large molecules mass and derivatization step of analytes is not necessary. Specific types of stationary and mobile phases allow for the simultaneous separation of broad range compounds from non-ionic group (NP, OP, OPEO) [7, 57] and even from ionic groups with better peak shapes and resolution of non-ionic oligomers [32]. The liquid chromatography for analysis of non-ionic compounds can be coupled with different types of detectors: fluorescence (FLD) [58], ultra-violet (UV) [59, 60], mass spectrometry (MS) [61] or their combination (MS-MS, UV-FLD, UV-MS [25, 62]). The facilities of LC-MS can be successfully applied for determination different types of the homologues and oligomers of alkylphenol ethoxylates and their metabolites [63]. The MS-MS detector can be used to identification of non-ionics analytes (due to their mass spectra contain characteristic fragments that constitute additional confirmation) and usually provides higher selectivity at quantitative determination step [64]. For ionization of non-ionic analytes were applied two techniques: atmospheric pressure chemical ionization (APCI) [26] and electrospray ionization ESI (has demonstrated higher sensitivity) [17,63]. The identification and quantitative analysis of non-ionic SAA was performed with the ion trap mass, quadrupole and triple-quadrupole mass spectrometers [64-67].

\section{The concentration of non-ionic surfactants in environmental samples}

The most studies were focused on determination concentrations of limited analytes from the group of APE, mainly in effluents and influents wastewaters [68]. Typically, the low molecular weight ethoxymers like nonylphenol monoethoxylate $\left(\mathrm{NP}_{1} \mathrm{EO}\right)$, nonylphenol diethoxylate $\left(\mathrm{NP}_{2} \mathrm{EO}\right)$, carboxylated derivatives nonylphenoxyacetic acid $\left(\mathrm{NP}_{1} \mathrm{EC}\right)$, and nonylphenoxyethoxyacetic acid $\left(\mathrm{NP}_{2} \mathrm{EC}\right)$ were determined during analysis. Also were interested occurrences of NP and OP compounds in different type of samples [7]. In Table 2 are given concentration of non-ionic surfactants in liquid samples and in Table 3 in solid samples. The total concentration of compounds from the group of NPEO in surface water samples (sea water) was range $0.9-1.2 \mu \mathrm{g} / \mathrm{dm}^{3}$. Effluent and influent wastewaters contain nonylphenol ethoxylate $\left(\mathrm{NP}_{0-16} \mathrm{EO}\right)$ in range $26.8 \mu \mathrm{g} / \mathrm{dm}^{3}$ and $3.52-756 \mu \mathrm{g} / \mathrm{dm}^{3}$, respectively. In turn, such samples contain octylphenol ethoxylate $\left(\mathrm{OP}_{0-16} \mathrm{EO}\right)$ in range $1.55 \mu \mathrm{g} / \mathrm{dm}^{3}$ and $0.21-6.45 \mu \mathrm{g} / \mathrm{dm}^{3}$, respectively. The carboxylated derivatives of NPEO and OPEO were occurred in wastewater samples in range from $1.5-16.8 \mu \mathrm{g} / \mathrm{dm}^{3}$ (effluent stream) and $81.5 \mu \mathrm{g} / \mathrm{dm}^{3}$ (influent stream). Compounds like $\mathrm{NP}$ $\left(<\mathrm{LOD}-200 \mathrm{ng} / \mathrm{dm}^{3}\right)$ and OP $\left(<\mathrm{LOQ}-37.6 \mathrm{ng} / \mathrm{dm}^{3}\right)$ were establish in liquid samples. The total concentration of compounds from the group of NPEO in sediment samples was range from 260 to $2700 \mu \mathrm{g} / \mathrm{kg}$ and in soil treated with sludge from 92 to $329 \mu \mathrm{g} / \mathrm{kg}$. The total concentration of compounds from the group of OPEO in sediment samples in soil treated with sludge was range from 87 to $369 \mu \mathrm{g} / \mathrm{kg}$. In sediment and in soil samples was confirmed occurrence of ASE compounds (respectively 114-266 $\mu \mathrm{g} / \mathrm{kg}$ and $<\mathrm{LOD}-152 \mu \mathrm{g} / \mathrm{kg}$. The NP (<LOD - $1100 \mu \mathrm{g} / \mathrm{kg})$ and OP $(0.2-238 \mu \mathrm{g} / \mathrm{kg})$ analytes were also found in solid samples. 
The analytical procedures used during determination of non-ionic surfactants and their levels in liquid environmental samples

\begin{tabular}{|c|c|c|c|c|c|}
\hline Analytes & Type of sample & $\begin{array}{l}\text { Isolation } \\
\text { technique }\end{array}$ & $\begin{array}{c}\text { Final } \\
\text { determination } \\
\text { technique }\end{array}$ & $\begin{array}{c}\text { Concentration of } \\
\text { analytes }\end{array}$ & Literature \\
\hline $\begin{array}{l}\text { Sum of } \\
\text { NPEO }\end{array}$ & Sea water & \multirow{25}{*}{ SPE } & \multirow{3}{*}{ LC-MS-MS } & $0.9-1.2 \mu \mathrm{g} / \mathrm{dm}^{3}$ & {$[21]$} \\
\hline $\mathrm{NP}_{0-3} \mathrm{EO}$ & $\begin{array}{c}\text { Wastewater - } \\
\text { effluent }\end{array}$ & & & $21.6 \mu \mathrm{g} / \mathrm{dm}^{3}$ & \multirow{13}{*}{ [7] } \\
\hline $\mathrm{NP}_{0-3} \mathrm{EO}$ & $\begin{array}{l}\text { Wastewater - } \\
\text { influent }\end{array}$ & & & $3.19-158 \mu \mathrm{g} / \mathrm{dm}^{3}$ & \\
\hline $\mathrm{NP}_{1} \mathrm{EO}$ & \multirow{5}{*}{ River water } & & \multirow{5}{*}{ LC-MS } & n.q. $-67 \mathrm{ng} / \mathrm{dm}^{3}$ & \\
\hline $\mathrm{NP}_{2} \mathrm{EO}$ & & & & $12-48 \mathrm{ng} / \mathrm{dm}^{3}$ & \\
\hline $\mathrm{NP}_{3} \mathrm{EO}$ & & & & $9-59 \mathrm{ng} / \mathrm{dm}^{3}$ & \\
\hline $\mathrm{NP}_{4} \mathrm{EO}$ & & & & $12-52 \mathrm{ng} / \mathrm{dm}^{3}$ & \\
\hline $\mathrm{NP}_{5} \mathrm{EO}$ & & & & $14-21 \mathrm{ng} / \mathrm{dm}^{3}$ & \\
\hline $\mathrm{NP}_{4-16} \mathrm{EO}$ & $\begin{array}{c}\text { Wastewater - } \\
\text { effluent }\end{array}$ & & \multirow{11}{*}{ LC-MS-MS } & $5.22 \mu \mathrm{g} / \mathrm{dm}^{3}$ & \\
\hline $\mathrm{NP}_{4-16} \mathrm{EO}$ & $\begin{array}{l}\text { Wastewater - } \\
\text { influent }\end{array}$ & & & $0.334-474 \mu \mathrm{g} / \mathrm{dm}^{3}$ & \\
\hline $\mathrm{NP}_{0-16} \mathrm{EO}$ & $\begin{array}{c}\text { Wastewater - } \\
\text { effluent }\end{array}$ & & & $26.8 \mu \mathrm{g} / \mathrm{dm}^{3}$ & \\
\hline $\mathrm{NP}_{0-16} \mathrm{EO}$ & $\begin{array}{l}\text { Wastewater - } \\
\text { influent }\end{array}$ & & & $3.52-726 \mu \mathrm{g} / \mathrm{dm}^{3}$ & \\
\hline $\mathrm{OP}_{0-5} \mathrm{EO}$ & $\begin{array}{c}\text { Wastewater - } \\
\text { effluent }\end{array}$ & & & $1.58 \mu \mathrm{g} / \mathrm{dm}^{3}$ & \\
\hline $\mathrm{OP}_{0-5} \mathrm{EO}$ & $\begin{array}{l}\text { Wastewater - } \\
\text { influent }\end{array}$ & & & $0.21-6.45 \mu \mathrm{g} / \mathrm{dm}^{3}$ & \\
\hline $\mathrm{OP}_{1} \mathrm{EO}$ & \multirow{5}{*}{ River water } & & & n.q. $(<9) \mathrm{ng} / \mathrm{dm}^{3}$ & \multirow{5}{*}[23]{} \\
\hline $\mathrm{OP}_{2} \mathrm{EO}$ & & & & n.q. $(<8) \mathrm{ng} / \mathrm{dm}^{3}$ & \\
\hline $\mathrm{OP}_{3} \mathrm{EO}$ & & & & n.q. $(<11) \mathrm{ng} / \mathrm{dm}^{3}$ & \\
\hline $\mathrm{OP}_{4} \mathrm{EO}$ & & & & n.q. $(<14) \mathrm{ng} / \mathrm{dm}^{3}$ & \\
\hline $\mathrm{OP}_{5} \mathrm{EO}$ & & & & n.q. $(<12) \mathrm{ng} / \mathrm{dm}^{3}$ & \\
\hline $\begin{array}{l}\text { Sum of } \\
\text { AEO }\end{array}$ & Sea water & & LC-MS & n.d. & [21] \\
\hline \multirow{3}{*}{ NP } & Tap water & & LC-MS-MS & $0.1 \mu \mathrm{g} / \mathrm{dm}^{3}$ & [69] \\
\hline & \multirow{4}{*}{ River water } & & GC-MS-MS & n.d. $-4.4 \mathrm{ng} / \mathrm{dm}^{3}$ & [70] \\
\hline & & & LC-MS-MS & $140-200 \mathrm{ng} / \mathrm{dm}^{3}$ & [23] \\
\hline \multirow{2}{*}{$\mathrm{OP}$} & & & GC-MS-MS & $37.6 \mathrm{ng} / \mathrm{dm}^{3}$ & [70] \\
\hline & & & \multirow{7}{*}{ LC-MS-MS } & n.q. & [23] \\
\hline $\begin{array}{c}\text { APEC } \\
\left(\mathrm{NP}_{1} \mathrm{EC}+\right. \\
\left.\mathrm{OP}_{1} \mathrm{EC}\right) \\
\end{array}$ & $\begin{array}{l}\text { Wastewater - } \\
\text { effluent }\end{array}$ & \multirow{2}{*}{ LLE } & & $1.5-16.8 \mu \mathrm{g} / \mathrm{dm}^{3}$ & \multirow{2}{*}{ [7] } \\
\hline $\begin{array}{c}\mathrm{APEC} \\
\left(\mathrm{NP}_{1} \mathrm{EC}+\right. \\
\left.\mathrm{OP}_{1} \mathrm{EC}\right) \\
\end{array}$ & $\begin{array}{l}\text { Wastewater - } \\
\text { influent }\end{array}$ & & & $81.5 \mu \mathrm{g} / \mathrm{dm}^{3}$ & \\
\hline $\mathrm{NP}_{1} \mathrm{EC}$ & $\begin{array}{c}\text { Wastewater - } \\
\text { influent }\end{array}$ & \multirow{4}{*}{ SPE } & & $182-478 \mu \mathrm{g} / \mathrm{dm}^{3}$ & \\
\hline $\mathrm{NP}_{2} \mathrm{EC}$ & \multirow{3}{*}{ Tap water } & & & $0.1 \mu \mathrm{g} / \mathrm{dm}^{3}$ & [69] \\
\hline $\mathrm{OP}_{1} \mathrm{EC}$ & & & & n.d. $\left(0.01 \mu \mathrm{g} / \mathrm{dm}^{3}\right)$ & \\
\hline $\mathrm{OP}_{2} \mathrm{EC}$ & & & & n.d. $\left(0.01 \mu \mathrm{g} / \mathrm{dm}^{3}\right)$ & \\
\hline
\end{tabular}


The analytical procedures used during determination of non-ionic surfactants and their levels in solid environmental samples

\begin{tabular}{|c|c|c|c|c|c|}
\hline Analytes & Type of sample & $\begin{array}{l}\text { Isolation } \\
\text { technique }\end{array}$ & $\begin{array}{c}\text { Final } \\
\text { determination } \\
\text { technique }\end{array}$ & $\begin{array}{l}\text { Concentration } \\
\text { of analytes }\end{array}$ & Literature \\
\hline \multirow{2}{*}{ Sum of NPEO } & Sediment & \multirow{2}{*}{ ASE } & \multirow{2}{*}{ LC-MS } & $260-2700 \mu \mathrm{g} / \mathrm{kg}$ & {$[21]$} \\
\hline & Soil treated with sewage & & & $92-329 \mu \mathrm{g} / \mathrm{kg}$ & [41] \\
\hline $\begin{array}{c}\text { Sum of } \\
\mathrm{NP}_{1} \mathrm{EO} \text { and } \\
\mathrm{NP}_{2} \mathrm{EO}\end{array}$ & Sediment & MAE & GC-MS & n.q.- $1.5 \mathrm{mg} / \mathrm{kg}$ & {$[46]$} \\
\hline Sum of OPEO & Soil treated with sewage & ASE & LC-MS & $87-369 \mu \mathrm{g} / \mathrm{kg}$ & {$[41]$} \\
\hline $\mathrm{NP}_{1} \mathrm{EO}$ & \multirow{24}{*}{$\begin{array}{l}\text { Particular matter in } \\
\text { sewage sample }\end{array}$} & \multirow{24}{*}{ SLE } & \multirow{24}{*}{ LC-MS-MS } & $2.6 \mu \mathrm{g} / \mathrm{kg}$ & \multirow{24}{*}[16]{} \\
\hline $\mathrm{NP}_{2} \mathrm{EO}$ & & & & $2.9 \mu \mathrm{g} / \mathrm{kg}$ & \\
\hline $\mathrm{NP}_{3} \mathrm{EO}$ & & & & $2.8 \mu \mathrm{g} / \mathrm{kg}$ & \\
\hline $\mathrm{NP}_{4} \mathrm{EO}$ & & & & $0.9 \mu \mathrm{g} / \mathrm{kg}$ & \\
\hline $\mathrm{NP}_{5} \mathrm{EO}$ & & & & $1.1 \mu \mathrm{g} / \mathrm{kg}$ & \\
\hline $\mathrm{NP}_{6} \mathrm{EO}$ & & & & $0.3 \mu \mathrm{g} / \mathrm{kg}$ & \\
\hline $\mathrm{NP}_{7} \mathrm{EO}$ & & & & $0.5 \mu \mathrm{g} / \mathrm{kg}$ & \\
\hline $\mathrm{NP}_{8} \mathrm{EO}$ & & & & $0.5 \mu \mathrm{g} / \mathrm{kg}$ & \\
\hline $\mathrm{NP}_{9} \mathrm{EO}$ & & & & $0.5 \mu \mathrm{g} / \mathrm{kg}$ & \\
\hline $\mathrm{NP}_{10} \mathrm{EO}$ & & & & $0.4 \mu \mathrm{g} / \mathrm{kg}$ & \\
\hline $\mathrm{NP}_{11} \mathrm{EO}$ & & & & $0.4 \mu \mathrm{g} / \mathrm{kg}$ & \\
\hline $\mathrm{NP}_{12} \mathrm{EO}$ & & & & $0.3 \mu \mathrm{g} / \mathrm{kg}$ & \\
\hline $\mathrm{OP}_{1} \mathrm{EO}$ & & & & $0.2 \mu \mathrm{g} / \mathrm{kg}$ & \\
\hline $\mathrm{OP}_{2} \mathrm{EO}$ & & & & $0.3 \mu \mathrm{g} / \mathrm{kg}$ & \\
\hline $\mathrm{OP}_{3} \mathrm{EO}$ & & & & $0.4 \mu \mathrm{g} / \mathrm{kg}$ & \\
\hline $\mathrm{OP}_{4} \mathrm{EO}$ & & & & $0.2 \mu \mathrm{g} / \mathrm{kg}$ & \\
\hline $\mathrm{OP}_{5} \mathrm{EO}$ & & & & $32.8 \mu \mathrm{g} / \mathrm{kg}$ & \\
\hline $\mathrm{OP}_{6} \mathrm{EO}$ & & & & $18.8 \mu \mathrm{g} / \mathrm{kg}$ & \\
\hline $\mathrm{OP}_{7} \mathrm{EO}$ & & & & $12.3 \mu \mathrm{g} / \mathrm{kg}$ & \\
\hline $\mathrm{OP}_{8} \mathrm{EO}$ & & & & $10.7 \mu \mathrm{g} / \mathrm{kg}$ & \\
\hline $\mathrm{OP}_{9} \mathrm{EO}$ & & & & $16.2 \mu \mathrm{g} / \mathrm{kg}$ & \\
\hline $\mathrm{OP}_{10} \mathrm{EO}$ & & & & $11.3 \mu \mathrm{g} / \mathrm{kg}$ & \\
\hline $\mathrm{OP}_{11} \mathrm{EO}$ & & & & $8.1 \mu \mathrm{g} / \mathrm{kg}$ & \\
\hline $\mathrm{OP}_{12} \mathrm{EO}$ & & & & $4.7 \mu \mathrm{g} / \mathrm{kg}$ & \\
\hline $\mathrm{NP}_{1} \mathrm{EC}$ & \multirow{2}{*}{ Sludge } & \multirow{4}{*}{ ASE } & \multirow{4}{*}{ LC-MS } & $7 \mu \mathrm{g} / \mathrm{kg}$ & [71] \\
\hline $\mathrm{NP}_{2} \mathrm{EC}$ & & & & $20 \mu \mathrm{g} / \mathrm{kg}$ & {$[/ 1]$} \\
\hline Sum of AEO & Sea sediment & & & $114-2666 \mu \mathrm{g} / \mathrm{kg}$ & {$[21]$} \\
\hline Sum of AEO & Soil treated with sludge & & & n.d. $-152 \mu \mathrm{g} / \mathrm{kg}$ & [41] \\
\hline \multirow{6}{*}{ NP } & \multirow{2}{*}{ Sediment } & \multirow{2}{*}{ MAE } & GC-MS & $0.14-1.1 \mathrm{mg} / \mathrm{kg}$ & [46] \\
\hline & & & GC-MS-MS & n.d. $-11 \mu \mathrm{g} / \mathrm{kg}$ & [70] \\
\hline & Soil treated with sewage & ASE & LC-MS & $142-500 \mu \mathrm{g} / \mathrm{kg}$ & [41] \\
\hline & $\begin{array}{c}\text { Particular matter in } \\
\text { sewage sample }\end{array}$ & SLE & \multirow[t]{2}{*}{ LC-MS-MS } & $0.8 \mu \mathrm{g} / \mathrm{g}$ & [16] \\
\hline & \multirow{2}{*}{ Sludge } & ASE & & $190 \mu \mathrm{g} / \mathrm{kg}$ & {$[71]$} \\
\hline & & UAE & LC-MS & $172-601 \mu \mathrm{g} / \mathrm{kg}$ & [22] \\
\hline \multirow{3}{*}{$\mathrm{OP}$} & River sediment & MAE & GC-MS-MS & $4.7-31.3 \mu \mathrm{g} / \mathrm{kg}$ & [70] \\
\hline & Soil treated with sewage & ASE & LC-MS & $105-238 \mu \mathrm{g} / \mathrm{kg}$ & [41] \\
\hline & $\begin{array}{c}\text { Particular matter in } \\
\text { sewage sample }\end{array}$ & SLE & LC-MS-MS & $0.2 \mu \mathrm{g} / \mathrm{g}$ & {$[16]$} \\
\hline
\end{tabular}




\section{Summary}

Compounds from the group of non-ionic surfactants are among the most prevalent anthropogenic pollutants with the potential to enter into the different ecosystems. The application of APEO in different field of human activity is very broad: cleaning products, cosmetics, plastics, paints, textiles, resins, petroleum refining, pesticides and metal processing.

This widespread use of surfactants coupled with the specific characteristics (bioaccumulation in living organism, chronic toxicity, ability to mimic natural hormones and disrupt endocrine functions) of that type of compounds provide necessity of investigation of their environmental occurrence [72, 73].

Analysis of compounds from the group of surfactants or their degradation products in environmental matrices is very complex and appropriate analytical techniques should be applied at sample preparation step and during separation, detection and quantification stages $[67,68]$. A lot of research has been done on the determination of non-ionic surface active agents and products of their metabolism in the aquatic and terrestrial ecosystems.

\section{References}

[1] Ying G-G. Environ Int. 2006;32:417-431. DOI: 10.1016/j.envint.2005.07.004.

[2] Holmberg K, Jönsson B, Kronberg B, Lindman B. Surfactants and Polymers in Aqueous Solution. Chichester: John Wiley \& Sons; 2003.

[3] Bloc SS. Disinfection, Sterilization, and Preservation. Philadelphia: Lippincott Williams \& Wilkins; 2001.

[4] Talmage SS. Environmental and Human Safety of Major Surfactants: Alcohol Ethoxylates and Alkylphenol Ethoxylates, A Report to the Soap and Detergent Association. Boca Raton: Lewis Publishers; 1994.

[5] Naylor CG, Mieure JP, Adams WJ, Weeks JA, Castaldi FJ, Ogle LD, Romano RR. J Am Oil Chem Soc. 1992;69,695-703. DOI: 10.1007/BF02635812.

[6] Thiele B. Surfactants. In: Nollet LML, editor. Chromatographic Analysis of the Environment. Boca Raton: CRC Press; 2005.

[7] Loyo-Rosales JE, Rice CP, Torrents A. Chemosphere. 2007;68:2118-2127. DOI: 10.1016/j.chemosphere.2007.02.002.

[8] Petrovic M, Barcelo D. Trend Anal Chem. 2004;23:762-771. DOI:10.1016/j.trac.2004.07.015.

[9] Hall WS, Patoczka JB, Mirenda RJ, Porter BA, Miller E. Arch Environ Contam Toxicol. 1988;18:765-772. DOI: $10.1007 / \mathrm{BF} 01225014$.

[10] Chen Y, Guo Z, Wang X, Qiu Ch. J Chromatogr A 2008;1184:191-219. DOI: 10.1016/j.chroma.2007.10.026.

[11] Van Ewijk PH, Hoekstra JA. Ecotoxicol Environ Saf. 1993;25:25-32. DOI: 10.1006/eesa.1993.1003.

[12] Verge C, Moreno A, Bravo J, Berna JL. Chemosphere. 2000;44:1749-1757. DOI: 10.1016/S0045-6535(00)00574-9.

[13] Scullion SD, Clench MR, Cooke M, Ashcroft AE. J Chromatogr A 1996;733:207-216. DOI: 10.1016/0021-9673(95)01188-9.

[14] Luque N, Merino F, Rubio S, Pérez-Bendito D. J Chromatogr A 2005;1094:17-23. DOI: 10.1016/j.chroma.2005.07.102.

[15] Łukaszewski Z, Szymański A, Wyrwas B. Trend Anal Chem. 1996;15:525-531. DOI: 10.1016/S0165-9936(96)00064-7.

[16] Vega Morales T, Torres Padron ME, Sosa Ferrera Z, Santana Rodriguez JJ. Trend Anal Chem. 2009;28:1186-1200. DOI: 10.1016/j.trac.2009.07.011.

[17] Crescenzi C, Di Corcia A, Marcomini A, Samperi R. Anal Chem. 1995;67:1797-1804. DOI: 10.1021/ac00107a008.

[18] Ferguson PL, Iden CR, Brownawell BJ. Anal Chem. 2000;72:4322-4330. DOI: 10.1021/ac000342n.

[19] Ahel M, Giger W. Chemosphere. 1993;26:1461-1470. DOI: 10.1016/0045-6535(93)90213-O.

[20] Di Corcia A, Samperi R, Marcomini A. Environ Sci Technol. 1994;28:850-858. DOI: 10.1021/es00054a016. 
[21] Lara-Martin PA, Gomez-Parra A, Gonzalez-Mazo E. Environ Poll. 2008;156:36-45. DOI: 10.1016/j.envpol.2008.01.005.

[22] Petrovic M, Barcelò D. Anal Chem. 2000;72:4560-4567. DOI: 10.1021/ac000306o.

[23] Loyo-Rosales JE, Schmitz-Afonso I, Rice CP, Torrents A. Anal Chem. 2003;75:4811-4817. DOI: $10.1021 / \mathrm{ac} 0262762$.

[24] Jahnke A, Gandrass J, Ruck W. J Chromatogr A. 2004;1035:115-122. DOI: 10.1016/j.chroma.2004.02.060.

[25] Loos R, Hanke G, Umlauf G, Eisenreich SJ. Chemosphere. 2007;66:690-699. DOI: 10.1016/j.chemosphere.2006.07.060.

[26] Castillo M, Ventura F, Barcelo D. Waste Manage. 1999;19:101-110. DOI: 10.1016/S0956-053X(99)00004-5.

[27] La Farre M, Klöter G, Petrovic M, Alonso MC, Lopez de Alda MJ, Barcelo D. Anal Chim Acta. 2002;456:19-30. DOI: 10.1016/S0003-2670(01)00908-4.

[28] Sanchez-Avila J, Bonet J, Velasco G, Lacorte S. Sci Total Environ. 2009;407:4157-4167. DOI: 10.1016/j.scitotenv.2009.03.016.

[29] Tobiszewski M, Mechlińka A. Namieśnik J. Chem Soc Rev. 2010;39:2869-2878. DOI: 10.1039/B926439F.

[30] Luo S, Fang L, Wang X, Liu H, Ouyang G, Lan C, Luan T. J Chromatogr A 2010;1217:6762-6768. DOI: 10.1016/j.chroma.2010.06.030.

[31] Zgoła-Grześkowiak A. J Chromatogr A 2010;1217:1761-1766. DOI: 10.1016/j.chroma.2010.01.054.

[32] Liu J-F, Hu X-L, Peng J-F, Jönsson JÅ, Mayer P, Jiang G-B. Anal Chem. 2006;78:8526-8534. DOI: $10.1021 / \mathrm{ac} 0615145$.

[33] Boyd-Boland AA, Pawliszyn J. Anal Chem. 1996;68:1521-1529. DOI: 10.1021/ac950902w.

[34] Pan Y-P, Tsai S-W. Anal Chim Acta. 2008;624:247-252. DOI: 10.1016/j.aca.2008.01.035.

[35] Basheer C, Parthiban A, Jayaraman A, Lee HK, Valiyaveetti S. J Chromatogr A 2005;1087:274-282. DOI: 10.1016/j.chroma.2005.03.014.

[36] Diaz A, Ventura F, Galceran MT. J Chromatogr A 2002;963:159-167. DOI: 10.1021/ac020124p.

[37] Braun P, Möder M, Schrader S, Popp P, Kuschk P, Engewald W. J Chromatogr A 2003;988:41-51. DOI: 10.1016/S0021-9673(02)02052-6.

[38] Petrovic M, Barcelo D. Chromatographia. 2002;56:535-544. DOI: 10.1007/BF02497667.

[39] Bennie DT, Sullivan CA, Lee H-B, Peart TE, Maguire RJ. Sci Tot Environ. 1997;193:263-275. DOI: 10.1016/S0048-9697(96)05386-7.

[40] Chiron S, Sauvard E, Jeannot R. Analusis. 2000;28:535-542. DOI: 10.1051/analusis:2000167.

[41] Andreu V, Ferrer E, Rubio JL, Font G, Picó Y. Sci Tot Environ. 2007;378:124-129. DOI: 10.1016/j.trac.2007.01.010.

[42] Jiménez-Díaz I, Ballesteros O, Zafra-Gómez A, Crovetto G, Vílchez JL, Navalón A. Chemosphere. 2010;80:248-255. DOI: 10.1016/j.chemosphere.2010.04.032.

[43] Petrovic M, Tavazzi S, Barcelo D. J Chromatogr A. 2002;971:37-45. DOI: 10.1016/S0021-9673(02)010269.

[44] Liu R, Zhou JL, Wilding A. J Chromatogr A. 2004;1038:19-26. DOI: 10.1016/j.chroma.2004.03.030.

[45] Croce V, Patrolecco L, Polesello S, Valsecchi S. Chromatographia. 2003;58:145-149. DOI: 10.1365/s10337-003-0032-8.

[46] Bartolomé L, Cortazar E, Raposo JC, Usobiaga A, Zuloaga O, Etxebarria N, et al. J Chromatogr A. 2005;1068:229-236. DOI: 10.1016/j.chroma.2005.02.003.

[47] Lee HB, Peart TE, Bennie DT, Maguire RJ. J Chromatogr A. 1997;785:385-394. DOI: 10.1016/S0021-9673(97)00384-1.

[48] Minamiyama M, Ochi S, Suzuki Y. J Environ Sci Health, Part A. 2007;43:1511-1515. DOI: 10.1080/10934520802293628.

[49] Field JA, Reed RL. Environ Sci Technol. 1999;33:2782-2787. DOI: 10.1021/es990038f.

[50] Bruno F, Curini R, di Corcia A, Fochi I, Nazzari M, Samperi R. Environ Sci Technol. 2002;36:4156-4761. DOI: $10.1021 / \mathrm{es} 020002 \mathrm{e}$.

[51] Zhu Z, Li Z, Hao Z, Chen J. Wat Res. 2003;37:4506-4512. DOI:.1016/S0043-1354(03)00379-8.

[52] Feitkenhauer H, Meyer U. Water Sci Technol. 2002;45:61-68. DOI: 10.1016/S0043-1354(03)00379-8.

[53] Giannetto M, Minari C, Mori G. Electroanalysis 2003;15:1598-1605. DOI: 10.1002/elan.200302727.

[54] Szymański A, Wyrwas B, Łukaszewski Z. Anal Chim Acta. 1995;305:256-264. DOI: 10.1016/0003-2670(94)00339-N.

[55] Szymański A, Wyrwas B, Bubień E, Kurosz T, Hreczuch W, Zembrzuski W, Łukaszewski Z. Wat Res. 2003;37:281-288. DOI: 10.1016/S0043-1354(02)00275-0. 
[56] Valls M, Bayona JM, Albaiges JJ. Environ Anal Chem. 1990;39:329-348. DOI: $10.1080 / 03067319008030506$.

[57] Ferguson PL, Iden CR, Brownawell BJ. J Chromatogr A. 2001;938:79-91. DOI: 10.1016/S0021-9673(01)01091-3.

[58] Núñez L, Turiel E, Tadeo JL. J Chromatogr A. 2007;1146:157-163. DOI: 10.1016/j.chroma.2007.01.101.

[59] Datta S, Loyo-Rosales JE, Rice CP. J Agric Food Chem. 2002;50:1350-1354. DOI: 10.1021/jf0111357.

[60] Gentili A, Marchese S, Perret D. Trend Anal Chem. 2008;27:888-903. DOI: 10.1016/j.trac.2008.07.008.

[61] Petrovic M, Barcelo D. J Mass Spectrom. 2001;36:1173-1185. DOI: 10.1002/jms.234.

[62] Cantero M, Rubio S, Perez-Bendito D. J Chromatogr A. 2004;1046:147-153. DOI: 10.1016/j.chroma.2004.06.073.

[63] Zwiener C, Frimmel FH. Anal Bioanal Chem. 2004;378:862-874. DOI: 10.1007/s00216-003-2412-1.

[64] Cantero M, Rubio S, Pérez-Bendito D. J Chromatogr A. 2005;1067:161-170. DOI: 10.1016/j.chroma.2004.11.017.

[65] Andreu V, Picó Y. Anal Chem. 2004;76:2878-2885. DOI: 10.1021/ac035483e.

[66] Lara-Martin PA, Gomez-Parra A, Gonzalez-Mazo E. Trend Anal Chem. 2008;27:684-695. DOI: 10.1016/j.trac.2008.05.005.

[67] Olkowska E, Polkowska Ż, Namiesnik J. Talanta 2012;88:1-13. DOI: 10.1016/j.talanta.2011.10.034.

[68] Olkowska E, Polkowska Ż, Namiesnik J. Chem Rev. 2011;111:5667-5700. DOI: 10.1021/cr100107g.

[69] Tubau I, Vázquez-Suńé E, Carrera J, González S, Petrovic M, de Alda MJL, Barceló D. J Hydrology 2010;383:83-92. DOI: 10.1016/j.jhydrol.2009.11.030.

[70] Hibberd A, Maskaoui K, Zhang Z, Zhou JL. Talanta 2009;77:1315-1321. DOI: 10.1016/j.talanta.2008.09.006.

[71] Petrovic M, Barceló D, Diaz A, Ventura F. J Am Soc Mass Spectrom. 2003;14:516-527. DOI: 10.1016/S1044-0305(03)00139-9.

[72] Olkowska E, Ruman M, Kowalska A, Polkowska Ż. Ecol Chem Eng S 2013;20(1):69-77. DOI: 10.2478/eces-2013-0005.

[73] Olkowska E, Ruman M, Kowalska A, Polkowska Ż. Ecol Chem Eng S 2013;20(2):331-342. DOI: 10.2478/eces-2013-0024.

\title{
OZNACZANIE POZIOMÓW ZAWARTOŚCI SURFAKTANTÓW W PRÓBKACH ŚRODOWISKOWYCH. CZĘŚĆ III. NIEJONOWE ZWIĄZKI
}

\author{
${ }^{1}$ Politechnika Gdańska \\ ${ }^{2}$ Uniwersytet Śląski, Sosnowiec \\ ${ }^{3}$ Instytut Badawczy Leśnictwa, Raszyn
}

\begin{abstract}
Abstrakt: Niejonowe surfaktanty stanowią zróżnicowaną grupę związków chemicznych, które w swojej budowie zawierają pozbawioną ładunku polarną „,głowę” i niepolarny „,gon”. Tego typu związki powierzchniowo czynne ze względu na amfifilową strukturę posiadają różnorodne właściwości. Komercyjnie dostępne produkty zawsze zawierają szerokie spektrum związków o niejonowym charakterze. Niejonowe związki znalazły zastosowanie głównie w gospodarstwach domowych oraz w przemyśle przy wytwarzaniu produktów czyszczących, włókienniczych, celulozowych i papierniczych, kosmetyków, farb, powłok konserwujących, żywic, produktów naftowych i pestycydów. Jest to jedna z najczęściej wykorzystywanych klas surfaktantów, które mogą stanowić potencjalne źródło zanieczyszczenia różnych elementów środowiska (ze względu na ich szerokie zastosowanie lub kierowanie oczyszczonych ścieków do wód powierzchniowych i stosowania osadów czynnych w rolnictwie). Istotne staje się badanie losu środowiskowego substancji powierzchniowo czynnych oraz ich wpływu względem organizmów żywych (ze względu na działanie toksyczne i zdolność do wpływu na funkcje endokrynologiczne). Te zagadnienia mogą być rozwiązywane przez stosowanie odpowiednich narzędzi analitycznych. Etap przygotowania próbek do analizy jest jednym z najważniejszych etapów procedur analitycznych. Tradycyjne techniki ekstrakcji (LLE - dla próbek ciekłych; SLE - dla próbek stałych) cechują się czasochłonnością oraz używaniem dużych ilości rozpuszczalników. Rozwój w tym zakresie doprowadził do poprawy efektywności izolacji analitów oraz zmniejszenia wymaganych objętości rozpuszczalników (np. SPE i SPME - próbki ciekłe lub PLE, SFE i MAE - próbki stałe). Na etapie oznaczania końcowego mogą być wykorzystane: technika spektrofotometryczna, technika miareczkowania potencjometrycznego lub tensammetria (do określania sumarycznego stężenie niejonowych związków powierzchniowoczynnych) oraz techniki
\end{abstract}


chromatograficzne (do określania poziomów stężenie pojedynczych analitów). Analiza danych literaturowych dotyczących stężeń surfaktantów w różnych elementach środowiska pozwala na stwierdzenie, że różne ekosystemy są zanieczyszczone przez związki o charakterze niejonowym.

Słowa kluczowe: niejonowe surfaktanty, izolacja i/lub wzbogacanie, etap oznaczania końcowego, próbki środowiskowe 